\title{
Symbiotic efficiency and genetic characteristics of Bradyrbizobium sp. strain UFSM LA 1.3 isolated from Lupinus albescens (H. et Arn)
}

\author{
Marcos Roberto Dobler Stroschein ${ }^{1}$; Flávio Luiz Foletto Eltz ${ }^{1 \%}$; Zaida Inês Antoniollii; \\ Manoeli Lupatini ${ }^{1}$; Luciano Kaiser Vargas ${ }^{2}$; Adriana Giongo ${ }^{3}$; Mateus Padoin Pontelli ${ }^{1}$ \\ ${ }_{2}^{1}$ UFSM - Depto. de Solos, Campus Universitário, Av. Roraima, 1000 - 97105-900 - Santa Maria, RS - Brasil. \\ ${ }_{3}^{2}$ Fepagro - R. Gonçalves Dias, 570 - 90130-060 - Porto Alegre, RS - Brasil. \\ ${ }^{3}$ UFRGS - Depto. de Genética, Av. Bento Gonçalves, 9500 - 91501-970 - Porto Alegre, RS - Brasil. \\ *Corresponding author <feltz@ccr.ufsm.br>
}

\begin{abstract}
Legume species belonging to the genus Lupinus are annual herb plants. The majority of them are indigenous to the Americas. They are known for nitrogen-fixing symbioses with soil bacteria collectively called rhizobia. The aim of this study was to characterize a rhizobium strain isolated from Lupinus albescens using phenotypic, symbiotic and molecular approaches. Strain UFSM LA 1.3 was tested in vitro according to several parameters: colony size, color and growing rate; acid or alkaline reaction in yeast mannitol media supplemented with bromothymol blue; gum production. Molecular characterization was evaluated by PCR technique using primers BOX A1-R and sequence analysis of the 16S-23S rDNA intergenic region (ITS). ITS sequencing fragments showed genetic similarity with Bradyrbizobium sp. The polymorphism observed by BOX-PCR have shown that strain differs from the reference strain SEMIA 928 and SEMIA 938. The symbiotic efficiency under axenic conditions of UFSM LA 1.3 was $94.6 \%$, without statistical differences compared to the mineral nitrogen fertilized control, to which was applied solution of $400 \mathrm{mg}$ of ammonium nitrate.
\end{abstract}

Key words: lupin, rhizobia, genotypic approaches

\section{Eficiência simbiótica e características genéticas da estirpe UFSM LA 1.3 de Bradyrbizobium sp. isolado de Lupinus albescens (H. et Arn)}

\begin{abstract}
RESUMO: Espécies de leguminosas pertencentes ao gênero Lupinus são plantas herbáceas anuais. A maioria é originária das Américas. Estas plantas estabelecem simbioses com bactérias do solo que realizam fixação biológica de nitrogênio coletivamente chamada de rizóbios. Caracterizou-se uma estirpe isolada de Lupinus albescens por meio de características fenotípicas, simbióticas e moleculares. A estirpe UFSM LA 1.3 foi testada in vitro de acordo com os parâmetros: tamanho de colônia; cor e taxa de crescimento; reação ácida ou básica em meio levedura manitol suplementado com azul de bromotimol; produção de goma. A caracterização molecular foi feita pela técnica de PCR usando os oligonucleotídeos BOX A1-R e seqüenciamento da região ITS. A análise da seqüência dos fragmentos da região intergênica (ITS) 16S-26S rDNA mostrou similaridade genética com Bradyrbizobium sp. O polimorfismo observado por BOX-PCR demonstrou que a estirpe difere das estirpes referência SEMIA 928 e SEMIA 938. A eficiência simbiótica de UFSM LA 1.3 foi de 94,6\%, sem diferenças estatísticas comparada com o controle com fertilizante nitrogenado mineral que recebeu $400 \mathrm{mg}$ de nitrato de amônio.
\end{abstract}

Palavras-chave: tremoço, rizóbio, análise genética

\section{Introduction}

The Southwest region of the state of Rio Grande do Sul (RS), Brazil, has about $5.2 \%$ of the area occupied by sandy soils. Lupinus albescens H. et Arn, a wild species, has been used in the recovery of sandy soils due to its strong adaptability to sandy soils, reducing eolic erosion and fixing nitrogen when associated to rhizobia (Rovedder and Eltz, 2008).

Microsymbionts from Lupinus spp. are little characterized (Zakhia and Lajudie, 2001), but some species were isolated from lupin species such as Bradyrbizobium, Rhizobium, Ocbrobactrum and Mesorbizobium (Tujilo et al., 2005; Jarabo-Lorenzo et al., 2003; Stepkowski et al., 2007; Jordan, 1984). Characterization of rhizobia is fundamental in diversity and identification studies of these microorganisms (Lammel et al., 2007). Rhizobia can be distinguished not only based on morphology and growth in yeast mannitol agar (Fred and Waksman, 1932), but also using molecular biology techniques for strain characterization. Primers corresponding to consensus repetitive sequences dispersed in the eubacteria genome, known as BOX (enterobacterial repetitive sequences) create characteristic patterns when separated in agarose gels, providing discrimination on strain level (Versalovic et al., 1991). 
Sequences of $16 \mathrm{~S}$ rDNA are highly conserved among bacteria (Woese, 2006) and genetic variation within this gene is not always sufficient to differentiate strains within a species. Sequence analysis of the internally transcribed spacer (ITS) region between the $16 \mathrm{~S}$ and the $23 \mathrm{~S}$ rDNA is useful in studies of phylogenetic relationships among isolates and reference strains (Honeycutt et al., 1995; Kwon et al., 2005). A high sequence variation in the internally transcribed spacer (ITS) region has been observed in bradyrhizobia strains what makes ITS region a informative tool of Bradyrbizobium taxonomic (Willems et al., 2001). Native rhizobia able to nodule $L$. albescens are not described yet. The objectives of this study are to characterize a $L$. albescens isolate by phenotypic and molecular methods and evaluate its symbiotic efficiency.

\section{Material and Methods}

L. albescens plants were collected in an experimental area located in Alegrete, RS, Brazil (29039'58" S, $55^{\circ} 23^{\prime} 43^{\prime \prime}$ W) in a degraded area under sandy erosion processes. The region climate is classified by Köppen as Cfa, humid subtropical without dry season, with a raining fall about $1,400 \mathrm{~mm}$ per year (Rovedder and Eltz, 2008). The soil of the experimental area is a Quartzipsamments with $\mathrm{pH}$ of $4.5,947 \mathrm{~g} \mathrm{~kg}^{-1}$ sand, $48 \mathrm{~g}$ $\mathrm{kg}^{-1}$ clay, and $8 \mathrm{~g} \mathrm{~kg}^{-1}$ of organic matter. Fresh root nodules were collected from lupin plants and kept on silica gel. Rhizobia were isolated on 79 medium (Fred and Waksman, 1932) using standard procedures and purified by repeated streaking (Somasegaran and Hoben, 1994). To confirm their purity, isolates and reference strains were streaked on 79 agar supplemented with $0.025 \mathrm{~g} \mathrm{~L}^{-1}$ of Congo red dye and 79 agar supplemented with $0.1 \mathrm{~g}$ $\mathrm{L}^{-1}$ of bromothymol blue (Somasegaran and Hoben, 1994). Pure cultures were stored at $-20^{\circ} \mathrm{C}$ in $25 \%$ glycerol 79 broth and remain in a Germoplasm Bank.

The pure cultures were tested for the ability of nodulation and leghemoglobin formation, performed using the authentication of isolated. Seeds of $L$. albescens were surface-sterilized, pregerminated, and transferred into plastic pots containing a mixture of sterilized vermiculite and sand (2:1). After $48 \mathrm{~h}$ pots were inoculated with bacterial culture grown in 79 broth (Fred and Waksman, 1932). Plants were maintained in a greenhouse and were supplied with $\mathrm{N}$-free plant nutrient solution once a week (Sarruge, 1975). From the 265 isolateds in the first study, 50 showed characteristics to be Bradyrbizobium sp, but after submitted to authentication tests with $L$. albescens, only one (UFSM LA 1.3) fit in this gender and was chosen for analysis in this study.

Bradyrbizobium sp. strains SEMIA 928 and SEMIA 938 were used as reference strains able to nodulate and fix nitrogen in lupin plants. They are recommended by the Brazilian Ministry of Agriculture, Livestock and Provisioning as inoculants for European species of Lupinus, mainly L. albus and $L$. angustifolius. Rhizobium leguminosarum SEMIA 265 was also used as a genus comparison strain and is recommended as inoculant for Trifolium pratense. All the reference strains were obtained from the Biological Nitrogen Fixation Center / Fundação Estadual de Pesquisa Agropecuária (Fepagro), RS, Brazil.

UFSM LA 1.3 was tested for Gram reaction, cell shape, colony size, growing rate, $\mathrm{pH}$ range in 79 medium (Fred and Waksman, 1932) with bromothymol blue; presence of gummy substances and colony color (Somasegaran and Hoben, 1994). The strains were grown by seven days at $28^{\circ} \mathrm{C}$ in a YEM agar medium supplemented with Congo red dye (Somasegaran and Hoben, 1994). The strain UFSM LA 1.3 was cultivated in 79 broth during 7 days at $28^{\circ} \mathrm{C}$. DNA isolation was carried out by CTAB modified method (Moreira, 1998). DNA samples were kept at $-20^{\circ} \mathrm{C}$.

rep-PCR reactions were carried out using repetitive extragenic palindromic-PCR (BOX A1) primer [5' CTACGGCAAGGCGACGCTGACG 3' (Versalovic et al., 1994)]. The reactions were performed in a $25-\mu \mathrm{L}$ volume, containing $50 \mathrm{ng}$ of DNA template, $1 \mathrm{U}$ Taq DNA polymerase, $1 \mathrm{X}$ Taq DNA polymerase buffer, $15 \mathrm{mmol}$ $\mathrm{L}^{-1} \mathrm{MgCl}$, $200 \mathrm{mmol} \mathrm{L}^{-1} \mathrm{dNTPs}$ (Life Technologies) and 10 pmoles of each primer. A total of 37 cycles took place, as follows: one initial denaturation cycle at $95^{\circ} \mathrm{C}$ for 7 min, 35 cycles of denaturation at $94^{\circ} \mathrm{C}$ for $1 \mathrm{~min}$, annealing at $53^{\circ} \mathrm{C}$ for $1 \mathrm{~min}$., and extension at $65^{\circ} \mathrm{C}$ for $8 \mathrm{~min}$., and one final extension cycle at $65^{\circ} \mathrm{C}$ for $16 \mathrm{~min}$. Reactions were performed in a termocycler (MJ Research, INC. PTC - 100MT) and the fragments were visualized after electrophoresis. A molecular size marker $(1 \mathrm{~Kb}$ Plus DNA ladder, Gibco BRL) was run in all gels. The bands were analyzed by Gelpro-3.2 program (Media Cybernetics). The band profile in BOX-PCR gel was transformed in a bidimensional binary matrix, were 0 indicates the band absence and 1 the presence and the grouping carried out by PAST 1.69 (Palaeontological Statistics), using the algorithm UPGMA (Unweighted PairGroup Method with arithmetic mean) and Simpson coefficient.

ITS region 16S-23S rDNA was amplified with FGPS1490 [5'TGCGGCTGGATCACCTCCTT3', corresponding to $3^{\prime}$ end of $16 \mathrm{~S}$ rDNA (Parker, 2002)] and FGPS132'-38 [5'CCGGGTTTCCCCATTCGG3', corresponding to 5' end of the 23S rDNA (Normand et al., 1992)]. The cycles were: one initial denaturation cycle at $95^{\circ} \mathrm{C}$ for $3 \mathrm{~min}, 35$ cycles of denaturation at $94^{\circ} \mathrm{C}$ for $1 \mathrm{~min}$., annealing at $55^{\circ} \mathrm{C}$ for $1 \mathrm{~min}$., and extension at $72^{\circ} \mathrm{C}$ for 2 min., and one final extension cycle at $72^{\circ} \mathrm{C}$ for $3 \mathrm{~min}$. The fragment was sequencing using Mega BACE 500 (Amersham Biosciences). The UFSM LA 1.3 sequence was added to the GenBank - NCBI (accession number EU367996). Partial nucleotide sequences of the ITS 16S-23S rDNA from strains of Bradyrbizobium sp. (GenBank accession numbers: AF338851, AF514795, DQ311105, AY039018, EF436470, EU367996); B. canariense (GenBank accession numbers: EF694745, EF694747); B. liaoningense (GenBank accession numbers: AJ279301, AJ279302); B. yuanmingense (GenBank acces-

Sci. Agric. (Piracicaba, Braz.), v.67, n.6, p.702-706, November/December 2010 
sion numbers: AJ534606, AJ534607, AY386734); B. elkanii (GenBank accession numbers: AF293373, AF293374, AF293376); B. betae (GenBank accession number: AJ631967); B. japonicum (GenBank accession numbers: AF208507, AF208509, AF208506) were accessed and utilized in a cladogram construction. Nucleotide sequence homology searches in sequence databases were done with programs BLAST 2.0 and Megablast algorithm. The selected sequences were aligned by ClustalW algorithm and the phylogenetics relationships were accessed using Neighbor-joining method carried out by MEGA 4.0 (Tamura et al., 2007).

Evaluation of the capacity and symbiotic efficiency of rhizobial strain UFSM LA 1.3 and reference strain SEMIA 938 was performed in a greenhouse essay. Seeds of $L$. albescens were surface-sterilized, pregerminated, and transferred into plastic pots with a capacity of $1.5 \mathrm{~L}$, containing a mixture of sterilized vermiculite and sand (2:1). After $48 \mathrm{~h}$ pots were inoculated with bacterial grown in 79 broth (Fred and Waksman, 1932). Plants were maintained in a greenhouse and were supplied with $\mathrm{N}$-free plant nutrient solution once a week (Sarruge, 1975). Positive control received a solution of $400 \mathrm{mg}$ of ammonium nitrate per pot during all the experiment as $\mathrm{N}$ source.

After 55 days plants were harvested and dried at $65^{\circ} \mathrm{C}$ until they reached a constant weight, ground to pass through a $0.5-\mathrm{mm}$ sieve, and analyzed for nitrogen accumulation (Tedesco et al., 1995). The number of nodules, nodule dry weight, and dry matters were also measured. Statistical significance was determined by using the analysis of Scott-Knott test $(p<0.05)$. The index proposed by Brockwell et al. (1966) was used to characterize the relative symbiotic efficiency.

\section{Results and Discussion}

When submitted to BOX-PCR analysis strain UFSM LA 1.3 showed a very particular band profile comparing with reference strains SEMIA 928 and 938 (Figure 1). The reference strains SEMIA 928 and SEMIA 938 presented low polymorphism using this technique and could represent the same strain; only SEMIA 938 was kept for greenhouse experiments.

UFSM LA 1.3 DNA amplification presented nine bands with sizes ranging between 4888 and 192bp. This pattern was unique for this strain and it has been not observed in any other. Rhizobium sp. strain presents seven bands well defined with the size of 4507, 3643, 3320, 2791, 1335, 1053 and 192 bp. Two groups were formed with $60 \%$ molecular similarity, where the UFSM LA 1.3 isolated presented an $80 \%$ similarity with reference strains SEMIA 938 and 928 (Figure 2). The BOXPCR analysis was efficient to discriminate the isolates, even though it is not always adequate to phylogenetic approaches (Fernandes et al., 2003).

Most rhizobial strains contained one type of ITS region sequence (Kwon et al., 2005) which makes this region a very useful marker for phylogenetic analysis in these bacteria. A fragment of $846 \mathrm{bp}$ of the ITS sequence
16S-23S rDNA was obtained. Constructing the phylogeny with the aligned UFSM LA 1.3 sequence and sequences obtained from GenBank showed that the lupine isolate was closely related to Bradyrbizobium sp. ORS 199 (95\% homology) and Bradyrbizobium sp. ORS 3257 (92\% homology) (Figure 3). Jarabo-Lorenzo et al. (2003) studied bradyrhizobia species isolated from Lupinus spp. and indicated that the Bradyrbizobium strains nodulating this legume represent a huge heterogeneity and their phylogenetic relationships is far from being solved.

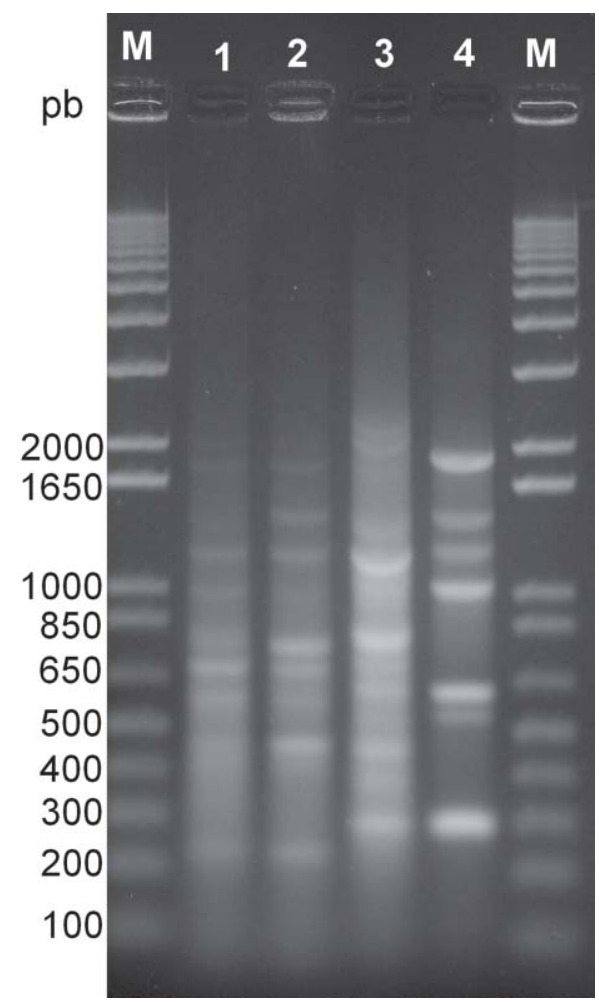

Figure 1 - Polymorphic patterns generated by BOX-PCR. (1) Bradyrbizobium sp. (SEMIA 938); (2) Bradyrbizobium sp. (SEMIA 928); (3) UFSM LA 1.3; (4) Rbizobium leuminosarum (SEMIA 265); (M) Marker $1 \mathrm{~Kb}$ Plus DNA Ladder (Gibco).

$\begin{array}{llllllllll}55 & 60 & 65 & 70 & 75 & 80 & 85 & 90 & 95 & 100\end{array}$

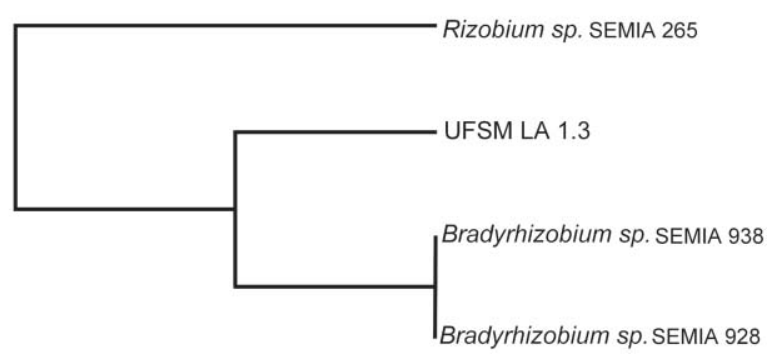

Figure 2 - Dendrogram built with UPGMA method and the Simpson coefficient based on BOX-PCR products obtained of strain UFSM LA 1.3 and other three rhizobial strains. 
Based on the experiments performed for phenotypic characterization strain, UFSM LA 1.3 presented a slow colony growing rate with generation time of $10-14 \mathrm{~h}$ forming convex, cream color, single, circular and mucoid colonies, reaching diameter of 1-2 $\mathrm{mm}$ after seven days of incubation at $28^{\circ} \mathrm{C}$ on 79 agar. It presented basic reaction in 79 media supplemented with bromothymol blue and low gum production. Bradyrbizobium genus presents these characteristics with exception of the cream color not frequently observed in this genus (Yao et al., 2002), although it has already been described to Bradyrbizobium strains isolated from Macroptylium atropurpureum in Amazonia (Lima et al., 2005).

Efficiency essays on biological nitrogen fixation have been carried out to select potential strains in inoculants

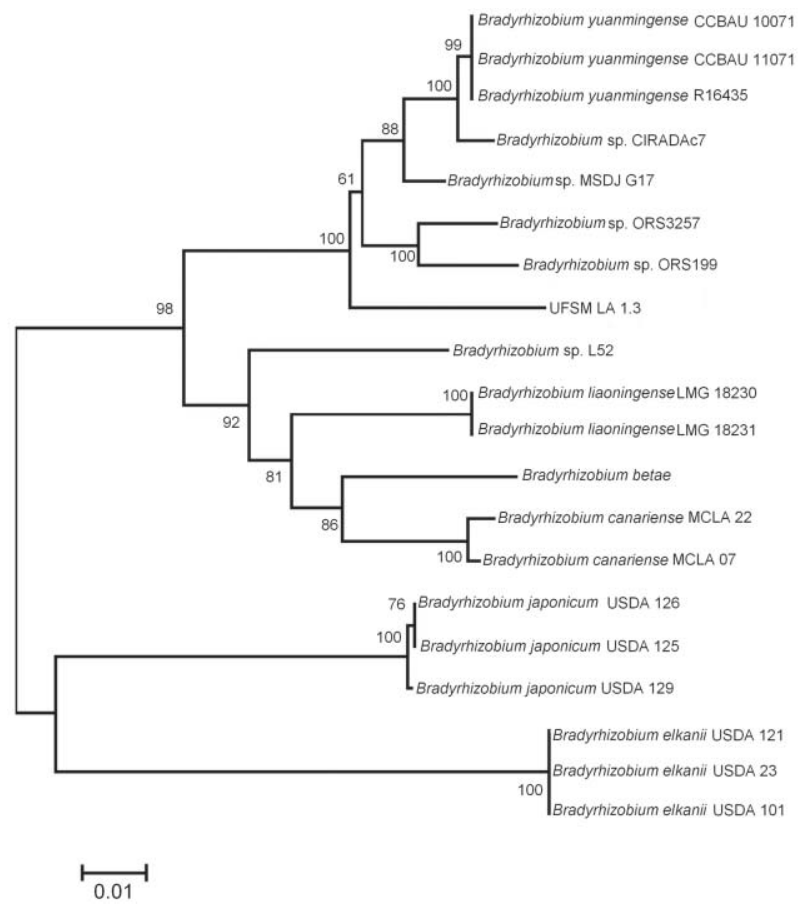

Figure 3 - Phylogenic tree based in the analysis Neighborjoining of the ITS region 16S-23S rDNA of UFSM LA 1.3 and related bradyrhizobia. The number in the ramifications represents the bootstrap value. production (Lima et al., 2005). UFSM LA 1.3 and SEMIA 938 were tested about shoot dry matter obtained and nitrogen content, symbiotic efficiency and number of nodules (Table 1). Strain UFSM LA 1.3 produced approximately $40 \%$ more shoot dry matter weight than SEMIA 938 without N supply. Strain SEMIA 938 did not differed to the negative control treatment.

Total $\mathrm{N}$ of the shoot matter of L. albescens demonstrated that strain UFSM LA 1.3 was similar to the positive control supplemented with $\mathrm{N}$, presenting a concentration of $31.9 \mathrm{~g} \mathrm{~kg}^{-1}$ and a relative symbiotic efficiency of $94.2 \%$. However, SEMIA 938 had similar results to the control (without $\mathrm{N}$ ), with a $\mathrm{N}$ concentration of 24.2 $\mathrm{g} \mathrm{kg}^{-1}$ with absence of nodule formation, demonstrating that strain SEMIA 938 is not an efficient L. albescens symbiont (Table 1). Bradyrbizobium strains isolated from Amazonian soils had symbiotic efficiency nearly $100 \%$ and a nitrogen accumulation higher than $30 \mathrm{~g} \mathrm{~kg}^{-1}$ (Lima et al., 2005).

Nodule formation processes depend and vary in function of plant genotype and strains involved, as well as environmental factors (Moreira and Siqueira, 2006). In this way, soil and climatic conditions found in the Pampa region could have contributed to the rhizobia natural selection of symbiotic strains to $L$. albescens. The SEMIA 938 was isolated from L. albus in the United States (Menna et al., 2006), what may explain its inefficiency in nodule formation and nitrogen fixation in $L$. albescens.

Usually a search for efficient rhizobia involves screening of a large number of isolates. Once isolates are purified, the main goal is to keep the maximum genetic diversity in the minimum number of isolates for further biological essays (Barriuso et al., 2005). In the present study we worked with only one isolate aiming to obtain an initial characterization of bacteria that can be able to fix nitrogen in association with $L$. albescens in Southwest RS, Brazil. In the present study, strain UFSM LA 1.3 is able to establish an effective $\mathrm{N}$ fixation in symbiosis with plants of the genus L. albescens, an important legume growing in a sandy area being used in the recovery of sandy soils of RS. Further studies about the performance of the rhizobia community in situ will uncover the potential of biological nitrogen fixation in this area.

Table 1 - Lupinus albescens response to inoculation with strains UFSM LA 1.3 and SEMIA 938.

\begin{tabular}{lcccc}
\hline Treatment & Dry matter & Nitrogen content & Number of nodules & Relative symbiotic efficiency \\
\hline UFSM LA 1.3 & mg per plant & $\mathrm{g} \mathrm{kg}^{-1}$ & 4 & $\%$ \\
SEMIA 938 & $135 \mathrm{a}$ & $31.9 \mathrm{a}$ & 0 & $94.2 \mathrm{a}$ \\
Control + N & $80 \mathrm{~b}$ & $24.2 \mathrm{~b}$ & 0 & $100.0 \mathrm{~b}$ \\
Control - N & $118 \mathrm{a}$ & $32.4 \mathrm{a}$ & $0.0 \mathrm{~b}$ \\
Coefficient of variation (\%) & $95 \mathrm{~b}$ & $23.8 \mathrm{~b}$ & 0 & 8.7 \\
\hline
\end{tabular}

Values in the same column followed by the same letter did not differ ( $p=0.05$, Scott-Knott test). Data presented are mean of four replicates for each strain. 


\section{Conclusions}

The UFSM LA 1.3 isolate had a high efficiency in the biological $\mathrm{N}$ fixation for Lupinus albescens, and showed phenotypic and molecular characteristics that allow locating this isolate in the Bradyrbizobium genus. The isolate presented low phylogenic relationship with described species for this genus until now, probably belonging to new Bradyrbizobium specie found in soil and climatic conditions under sandy soils and in Lupinus albescens plants.

\section{Acknowledgements}

To Eliane Bangel, from State Foundation of Agricultural Research (FEPAGRO), for providing the rhizobial reference strains. This work was supported by a grant and fellowships from National Council for Scientific and Technological Development (CNPq/Brazil).

\section{References}

Barriuso, J.; Pereyra, M.T.; Garcia, J.A.; Megias, M.; GutierrezMañero, F.J.; Ramos, B. 2005. Screening for Putative PGPR to Improve Establishment of the Symbiosis Lactarius deliciosus-Pinus sp. Microbial Ecology 50: 82-89.

Brockwell, J.; Hely, F.W.; Neal-Smith, C.A. 1966. Some symbiotic characteristics of rhizobia responsible for spontaneous, effective field nodulation of Lotus hispidus. Australian Journal of Experimental and Animal Husbandry 6: 365-370.

Fernandes, M.F.; Fernandes, R.P.; Hungria, M. 2003. Genetic characterization of indigenous rhizobia strains from the coastal tableland efficient for the pigeonpea and cowpea crops. Pesquisa Agropecuária Brasileira 38: 908-920. (in Portuguese, with abstract in English).

Fred, E.B.; Waksman, S.A. 1932. Manitol Agar Laboratory Manual of General Microbiology. McGraw-Hill, New York, NY, USA.

Honeycutt, R.J.; Sobral, B.W.S.; McClalland, M. 1995. tRNA intergenic spacers reveal polymorphisms diagnostic for Xanthomonas albilineans. Microbiology 141: 3229-3239.

Jarabo-Lorenzo, A.; Pérez-Galdona, R.; Donate-Correa, J.; Rivas, R.; Velázquez, E.; Hernández, M.; Temprano, F.; MartínezMolina, E.; Ruiz-Argüeso, T.; León-Barrios, M. 2003. Genetic diversity of bradyrhizobial populations from diverse geographic origins that nodulate Lupinus spp. and Ornithopus spp. Systematic and Applied Microbiology 26: 611-623.

Jordan, D.C. 1984. Family. III. Rhizobiaceae. p. 234-244. In: Krieg, N.R.; Holt, J.G., eds. Bergey's manual of systematic bacteriology. William \& Wilkins, Baltimore, MD, USA.

Kwon, S.W.; Park, J.; Kim, J.; Kang, J.; Cho, Y.; Lim, C.; Parker, M.A.; Lee, G. 2005. Phylogenetic analysis of the genera Bradyrhizobium, Mesorbizobium, Rhizobium and Sinorbizobium on the basis of $16 \mathrm{~S}$ rRNA gene and internally transcribed spacer region sequences. International Journal of Systematic and Evolutionary Microbiology 55: 263-270.

Lammel, D.R.; Brancalion, P.H.S.; Dias, C.T.S.; Cardoso, E.J.B.N. 2007. R Rhizobia and other legume nodule bacteria richness in Brazilian araucaria angustifolia forest. Scientia Agricola 64: 400-408.

Lima, A.S.; Pereira, J.P.A.R.; Moreira, F.M.A. 2005. Phenotypic diversity and symbiotic efficiency of Bradyrbizobium spp. strains from Amazonian soils Pesquisa Agropecuária Brasileira 40: 10951104. (in Portuguese, with abstract in English).

Menna, P.; Hungria, M.; Barcellos, F.G.; Bangel, E.V.; Hess, P.N.; Martínez-Romero, E. 2006. Molecular phylogeny based on the $16 \mathrm{~S}$ rRNA gene of elite rhizobial strains used in Brazilian commercial inoculants. Systematic and Applied Microbiology 29: 315-332.
Moreira, F.M.M.; Siqueira, J.O. 2006. Soil Microbiology and Biochemistry. Editora da UFLA, Lavras, MG, Brazil. (in Portuguese).

Moreira, D. 1998. Efficient removal of PCR inhibitors using agaroseembedded DNA preparations. Nucleic Acids Research 26: 33093310.

Normand, P.; Cournoyer, B.; Simonet, P.; Nazaret, S. 1992. Analysis of a ribosomal RNA operon in the actinomycete Frankia. Gene 111: 119-124.

Parker, M. 2002. Bradyrhizobia from Wild Phaseolus, Desmodium, and Macroptilium Species in Northern México. Applied and Environmental Microbiology 68: 2044-2048.

Rovedder, A.P.M.; Eltz, F.L.F. 2008. Revegetation with cover crops for soils under arenization and wind erosion in Rio Grande do Sul State, Brazil. Revista Brasileira de Ciência do Solo 32: 315321. (in Portuguese, with abstract in English).

Sarruge, J.R. 1975. Nutritive solutions. Summa Phitopathologica 1: 231-234. (in Portuguese, with abstract in English).

Soil Survey Staff. 1998. Soil Taxonomy. US Department of Agriculture, Soil Conservation Service. Washington, DC, USA.

Somasegaram, P.; Hoben, J.H. 1994. Methods in LegumeRhizobium Technology. Springer, New York, NY, USA.

Stepkowski, T.; Hughes, C.E.; Law, I.J.; Markiewicz, L.; Gurda, D.; Chlebicka, A.; Moulin, L. 2007. Diversification of lupine Bradyrhizobium strains: evidence from nodulation gene trees. Applied and Environmental Microbiology 73: 3254-3264.

Tamura, K., Dudley, J.; Nei, M.; Kumar, S. 2007. MEGA4: Molecular evolutionary genetics analysis (MEGA) software version 4.0. Molecular Biology and Evolution 24: 1596-1599.

Tedesco, M.J.; Gianello, C.; Bissani, C.A.; Bohnen, H.A.; Volkweis, S.I. 1995. Soil Analysis, Plants and Other Materials. 2ed. Universidade Federal do Rio Grande do Sul, Porto Alegre, RS, Brazil. (Technical bulletin, 5). (in Portuguese).

Tujilo, M.; Willems, A.; Abril, A.; Planchuelo, A.; Rivas, R.; Ludña, D.; Mateos, P.F.; Martívez-Molina, E. 2005. Nodulation of Lupinus albus by strains of Ochrobacytrum lupini sp. nov. Applied Environmental Microbiology 71: 1318-1327.

Versalovic, J.; Koeuth, T.; Lupski, J.R. 1991. Distribution of repetitive DNA sequences in eubacteria and application to fingerprinting of bacterial genomes. Nucleic Acids Research 19: 6823-6831.

Versalovic, J.; Schneider, M.; de Bruijn, F.J.; Lupski, J.R. 1994. Genomic fingerprinting of bacteria using repetitive sequencebased polymerase chain reaction. Methods in Molecular and Cellular Biology 5: 25-40.

Willems, A.; Cooperman, R.; Gillis, M. 2001. Comparison of sequence analysis of $16 \mathrm{~S}-23 \mathrm{~S} \mathrm{rDNA}$ spacer regions, AFLP analysis and DNA-DNA hybridizations in Bradyrhizobium. International Journal of Systematic and Evolutionary Microbiology 51: 623-632.

Woese, C.R. 2006. How we do, don't and should look at bacteria and bacteriology. p. 3-24. In: Dworkin, M.; Falkow, S.; Rosenberg, R.; Shleifer, K.; Stackebrandt, E., eds. The prokaryotes: a handbook on the biology of bacteria microbiological reviews. Springer, New York, NY, USA.

Yao, Z.Y.; Kan, F.L.; Wang, E.T.; Wei, G.H.; Chen, W.X. 2002. Characterization of rhizobia that nodulate legume species of the genus Lespedeza and description of Bradyrbizobium yuanmingense sp. International Journal of Systematic and Evolutionary Bacteriology 52: 2219-2230.

Zakhia, F.; Lajudie, P. 2001. Taxonomy of rhizobia. Agronomie 21: 569-576.

Received April 14, 2009

Accepted June 30, 2010 